\title{
Identification of progastrin derived peptides in colorectal carcinoma extracts
}

\author{
J Nemeth, ${ }^{\star}$ B Taylor, S Pauwels, A Varro, G J Dockray
}

\begin{abstract}
The possible production of gastrin by colorectal carcinomas has been studied. Extracts of 44 tumours and adjacent macroscopically normal tissue were examined in radioimmunoassay using the following antibodies: (i) L289 raised to a C-terminal fragment of progastrin which shows specificity for intact progastrin, but not the extreme C-terminal tryptic peptide; (ii) LW60 raised to a C-terminal fragment of progastrin which reacts with progastrin and its C-terminal tryptic peptide; (iii) 109-21 which was raised to, and reacts with, Gly-extended forms of heptadecapeptide gastrin - that is, biosynthetic intermediates on the pathway producing active gastrin; and (iv) $\mathbf{L} 2$ which reacts with amidated, biologically active gastrins. All samples contained detectable material in assays using $\mathrm{LW60}$; in general, concentrations measured with this antibody were higher than with the other antibodies, and in particular there were higher concentrations in tumour compared with normal tissue extracts.
\end{abstract} Tumour extracts also contained higher concentrations of immunoreactivity compared with normal tissue, in assays using antibodies L289 and 109-21. In contrast, amidated gastrins were found in similar concentrations in tumour and normal tissue, and concentrations were the lowest of those recorded in the four assays. Separation on Sephadex G50 revealed peaks compatible with progastrin and its C-terminal flanking peptide, and two other peaks that are so far unidentified. In conclusion most colorectal carcinomas contain peptides derived from the gastrin precursor, progastrin, but for the most part these tumours do not convert progastrin into biologically active products.

(Gut 1993; 34: 90-95)

In addition to their acute effects on gastrointestinal motility and secretion, regulatory peptides of the gut may also have mitogenic actions on gastrointestinal and other cells. In recent years it has become clear that certain tumour derived cell lines can be associated with the production of gut peptides, and that some of these peptides are mitogenic to the same cells. 'In the case of gastrin, cell lines derived from colorectal carcinomas have recently been shown to contain gastrin mRNA, ${ }^{2}$ and some human colorectal cancers in short term tissue culture release a peptide into the culture medium which appears to have the immunological characteristics of gastrin. ${ }^{3}$ Colorectal tumour cell lines may also express receptors specific for gastrin, ${ }^{+}$ and gastrin has been shown to be mitogenic to certain colorectal cancer cell lines in vitro and in transplantable tumours in vivo. ${ }^{5-7}$ Gastrin receptor blocking agents (either antagonists or antibodies) have been shown to bring about significant inhibition of growth in several cell lines. ${ }^{8-12}$

Together, the observations outlined above raise the possibility that gastrin might be acting as an autocrine growth factor in some colorectal cancers. It is well established that peptides derived from the gastrin precursor, progastrin, are produced in a number of tumours of endocrine origin, and it seems possible that some primary gastric and colorectal tumours may also contain gastrin. ${ }^{212}$ The latter point, however, has not yet been intensively studied. In the present study we have examined extracts prepared from 44 colorectal tumours, and from 'normal' mucosa, with a range of antibodies which together allow us to identify progastrin, its C-terminal fragment produced by tryptic cleavage, a biosynthetic intermediate (glycine extended gastrin), as well as biologically active (amidated) gastrins (Fig 1). The results show that progastrin derived peptides are commonly present in colorectal cancers, and suggest that they may be manufactured locally.

\section{Methods}

\section{PEPTIDES}

The C-terminal pentadecapeptide of human progastrin ie preprogastrin 87-101 was obtained from UCB Products (YGWMDFGRRSAEDEN, in the single letter notation); the C-terminal decapeptide of progastrin with Tyr in the first position - that is, $\left(\mathrm{Tyr}^{22}\right)$ preprogastrin $92-101$ (YGRRSAEDEN), was obtained from Multiple Peptide Systems (San Diego, CA, USA); Glyextended C-terminal octapeptide fragment of G17 ie preprogastrin 86-93 (AYGWMDFG), was a gift from $\mathrm{Dr} J$ Walsh. Other human progastrin fragments were obtained from Peninsula Ltd. Human G17 was a gift from the late Professor R A Gregory, and natural human progastrin was isolated from a gastrinoma as previously described. ${ }^{13-15}$

\section{PATIENTS AND TUMOURS}

An unselected, but approximately consecutive, series of 44 patients was studied presenting with colorectal cancers between June 1989 and November 1990 to the University Department of Surgery in Liverpool. All patients had sporadic tumours which were managed electively. Patients who presented as emergencies were excluded, as were patients treated during the same period of time with cancers arising in a 


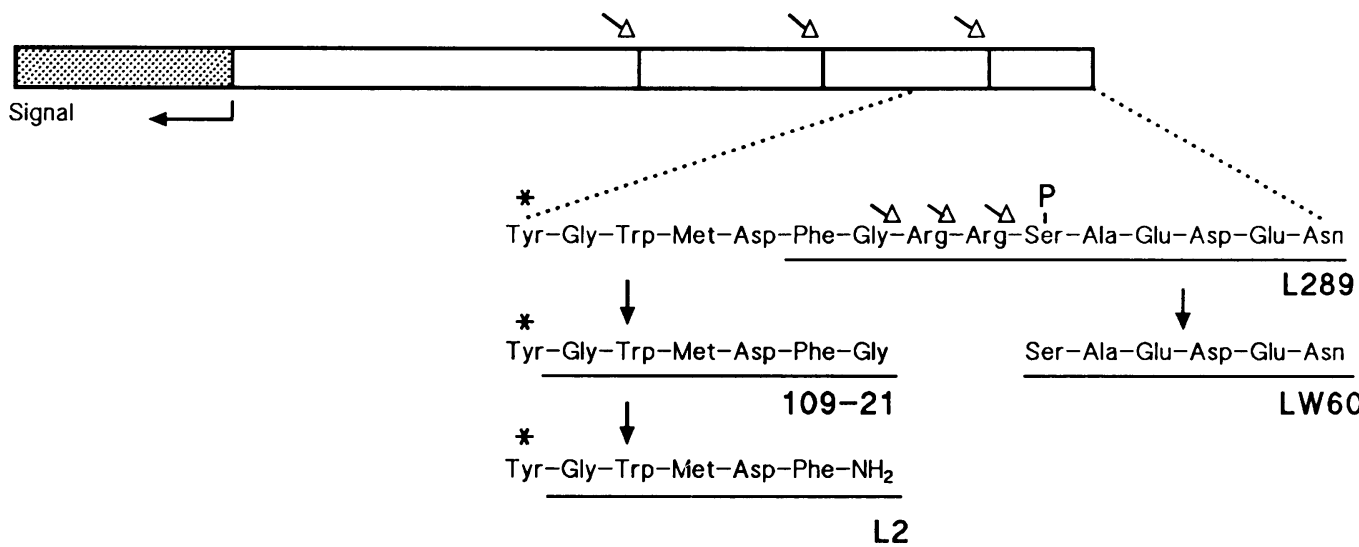

Figure 1: Schematic representation of human preprogastrin and its major products showing the specificity of antibodies used in the present study. The $C$-terminal region is shown in an expanded form. Cleavage at the Arg residues by endopeptidase and carboxypeptidase generates Gly-extended gastrin intermediates and the $C$-terminal tryptic peptide fragment. The Gly-extended intermediate is converted to amidated active products. Antibody $L 289$ reacts with $C$-terminal fragments of progastrin longer than eight residues, these include intact progastrins, but exclude the C-terminal tryptic peptide. The latter reacts with LW60 which also reveals intact progastrin, MAb 109-21, and L2 react with Gly extended and amidated peptides respectively.

background of familial Polyposis coli or long standing ulcerative colitis.

There was an equal sex distribution in the study group, with the majority of tumours (in both sexes) being located distally, in the rectum $(35 \%)$ or sigmoid colon $(30 \%)$. Other sites were involved less frequently: left colon, $5 \%$; transverse colon, $10 \%$; right colon and caecum, $20 \%$. The types of operative procedures undertaken are shown in Table I.

Upon removal from the patient, intestinal resection specimens were immediately opened along the antimesenteric border, and small pieces (c 2-5 $\mathrm{g}$ each) harvested under direct vision, both from the tumour itself and from normal looking mucosa as far distant from the tumour as was possible. Specimens were immediately frozen on dry ice until extracted (see below).

The majority $(88 \%)$ of the tumours studied were described histologically as moderately differentiated, with only a single tumour $(2 \%)$ described as well differentiated and the remainder $(10 \%)$, poorly differentiated. In terms of the stage of the disease, the majority were Dukes' stage B $(35 \%)$ or C $(33 \%)$, with only a few in Dukes' stage $A(12 \%)$. The remaining patients $(20 \%)$ had advanced disease, usually with liver metastases - that is, stage D, at the time of their initial surgery. In eight patients, there were other benign tumours within the resection specimen - that is, tubular adenomas or tubulovillous adenomas; these tumours were not sampled during the present study, while one patient had two separate, synchronous primary tumours (in the left colon and transverse colon). One patient also had a distal gastric cancer which was resected at the same time as the colonic primary.

TABLE I Operative procedures

\begin{tabular}{lr}
\hline Operation & \multicolumn{1}{c}{$\%$} \\
\hline Abdominoperineal excision of rectum & $12 \cdot 5$ \\
Anterior resection of rectum & $22 \cdot 5$ \\
Hartman's resection of rectum & $7 \cdot 5$ \\
Sigmoid colectomy & $22 \cdot 5$ \\
Left hemicolectomy & $5 \cdot 0$ \\
Transverse colectomy & $5 \cdot 0$ \\
Right, or extended right colectomy & $25 \cdot 0$ \\
\hline
\end{tabular}

EXTRACTS

Deeply frozen specimens were quickly weighed, boiled in water, homogenised and centrifuged as previously described. ${ }^{15}$ This extraction method gives good recovery of progastrin and its major products. Extracts were stored at $-20^{\circ} \mathrm{C}$ before assay or fractionation by gel filtration.

\section{ANTIBODIES}

The specificity of the various antibodies used in this study is shown schematically in Figure 1, and the antibody characteristics are listed in Table II. Antibody L2 has been shown to be specific for the C-terminus of amidated gastrins, ${ }^{16} 109-21$ for the C-terminus of Glyextended gastrins, ${ }^{17}$ and, antibody L289 for the C-terminus of progastrin. ${ }^{18}$ The latter antibody has high affinity for C-terminal fragments greater than eight residues and no appreciable affinity for the $\mathrm{C}$-terminal tryptic hexapeptide. The rabbit antiserum LW60 was raised by immunisation with preprogastrin 87-101

TABLE II Characteristics of antibodies used in radioimmunoassay in this study

\begin{tabular}{|c|c|c|c|}
\hline Antibody & Antigen & Specificity & $\begin{array}{l}\text { Detection } \\
\text { limit }\end{array}$ \\
\hline L289 & h prog $87-101^{\star}$ & $\begin{array}{l}\text { C-terminus progastrin } \\
>8 \text { residues }\end{array}$ & $0.4 \mathrm{pmol} / \mathrm{g}$ \\
\hline LW60 & h prog $87-101^{\star}$ & $\begin{array}{l}\text { C-terminus progastrin } \\
>5 \text { residues }\end{array}$ & $1.0 \mathrm{pmol} / \mathrm{g}$ \\
\hline $\begin{array}{l}109-21 \\
\text { L2 }\end{array}$ & $\begin{array}{l}\text { Gly-extended G6 } \\
\text { G17 }\end{array}$ & $\begin{array}{l}\text { G-gly } \\
\text { C-terminal amidated } \\
\text { gastrins }\end{array}$ & $\begin{array}{l}0.1 \mathrm{pmol} / \mathrm{g} \\
0.1 \mathrm{pmol} / \mathrm{g}\end{array}$ \\
\hline
\end{tabular}

^Human progastrin C-terminal pentadecapeptide.

TABLE III Specificity of antibody $L W 60^{\star}$

\begin{tabular}{ll}
\hline Peptide & $\begin{array}{l}\text { Relative immunochemical } \\
\text { potency }\end{array}$ \\
\hline Preprogastrin 22-101 & $1 \cdot 0$ \\
YGWMDFGRRSAEDEN & 1.0 \\
YGRRSAEDEN & 0.77 \\
RSAEDEN & 0.46 \\
SAEDEN & 0.53 \\
\hline ॠThe relative potency of various peptides in inhibiting binding of \\
label to antibody LW60 is shown. The concentration of peptide \\
required for inhibiting binding of label by $50 \%$ was divided by that \\
of progastrin. Peptide sequences are given in the single letter \\
notation.
\end{tabular}


coupled to bovine thyroglobulin using glutaraldehyde as previously described. ${ }^{13}$

In radioimmunoassay, antibody $\mathrm{LW} 60$ was used at a dilution of 1:65000 with $2000 \mathrm{cpm}$ of ${ }^{125}$ I labelled human progastrin $\left(\mathrm{Tyr}^{22}\right.$ 92-101). Assays were incubated in $1.0 \mathrm{ml} 0.02 \mathrm{M}$ sodium barbitone buffer pH 8.4 containing $0.05 \%$ w/v sodium azide and $0.75 \% \mathrm{v} / \mathrm{v}$ Bovumin (Orthodiagnostics), for 48 hours at $4^{\circ} \mathrm{C}$. Antibody bound and free label were separated by addition of $100 \mu \mathrm{l}$ of a suspension of charcoal:dextran:fat free milk powder $(10: 1: 0.5 \mathrm{~g}$ in $100 \mathrm{ml}$ distilled water) and centrifugation at $4^{\circ} \mathrm{C}$ for 10 minutes.

The specificity of assays with LW60 was established from comparison of the potency of a range of progastrin derived peptides and analogues in inhibiting binding of label (Table III). Peptides longer than the C-terminal hexapeptide were virtually equipotent in inhibiting binding. The standard used routinely was progastrin 93-101. In 10 consecutive assays the mean (SE) of the concentration of standard required for $50 \%$ inhibition of binding was 28.0 $(1 \cdot 6) \mathrm{pmol} / \mathrm{l}$. All assays routinely included tubes to assess non-specific binding which was typically less than $5 \%$ of total counts. Nonspecific binding of all tissue extracts was also determined by including tubes containing extract but no antibody - again non-specific binding was typically less than $5 \%$ total counts.

\section{GEL FILTRATION}

Samples of selected tumours and control tissue were fractionated on Sephadex G50 columns $(1 \times 95 \mathrm{~cm})$ eluted with $0.05 \mathrm{M}$ ammonium bicarbonate.

\section{STATISTICAL ANALYSIS}

Where appropriate the results are presented as means (SE). Comparisons between groups were made by Student's $t$ test, or Wilcoxon's matched pairs test.

\section{Results}

\section{PLASMA GASTRIN}

In the group as a whole the concentrations of amidated gastrin in fasting plasma were 10.8 $(2 \cdot 9) \mathrm{pmol} / \mathrm{l}$ which was well within the normal range for this assay $(<30 \mathrm{pM})$. Five of the 44 patients, however, had raised plasma gastrin concentrations $(34,36,47,83$, and $84 \mathrm{pM})$.

\section{TUMOUR GASTRINS}

Tissue extracts from all 44 patients contained immunoreactive material detected in assays using LW60 (Fig 2). The concentrations of immunoreactivity in the tumour extracts $(7 \cdot 53$ $(0.69) \mathrm{pmol} / \mathrm{g})$ were significantly higher than in adjoining apparently normal colon $(3.99(0.42) ; t$ test, $\mathrm{p}<0.001)$. In assays using antibody L289, specific for human progastrin derived peptides extending beyond the C-terminal region, there were significantly higher concentrations $(\mathrm{p}<0.001$, Wilcoxon) of immunoreactive material in tumour extracts $(1.54(0.2) \mathrm{pmol} / \mathrm{g}$, in

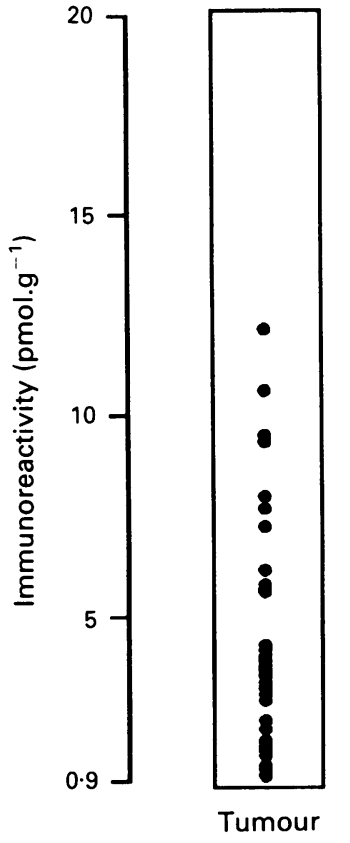

LW60

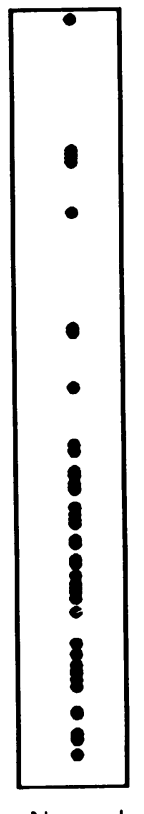

Figure 2: Scattergram of the distribution of immunoreactive material measured by antibody LW60 in 44 extracts of tumour and the corresponding normal colon.

40 of 44 patients) compared with control samples (of which only nine of 44 contained measurable activity, Figure 3 ). The mean concentrations of L289 immunoreactivity in the tumour extracts were about $20 \%$ those detected with LW60. The antibody for the Gly-extended intermediate showed detectable material in 20 of 44 tumours compared with seven normal samples and again concentrations were higher in the former than the latter ( $<<0 \cdot 001$, Wilcoxon) (Fig 4). Finally, amidated gastrins occurred in detectable amounts in a similar proportion of the tumour (19 of 44) and control ( 25 of 44 ) extracts and mean concentrations in these extracts were also similar (about $1 \mathrm{pmol} / \mathrm{g}$ ) (Fig 5).
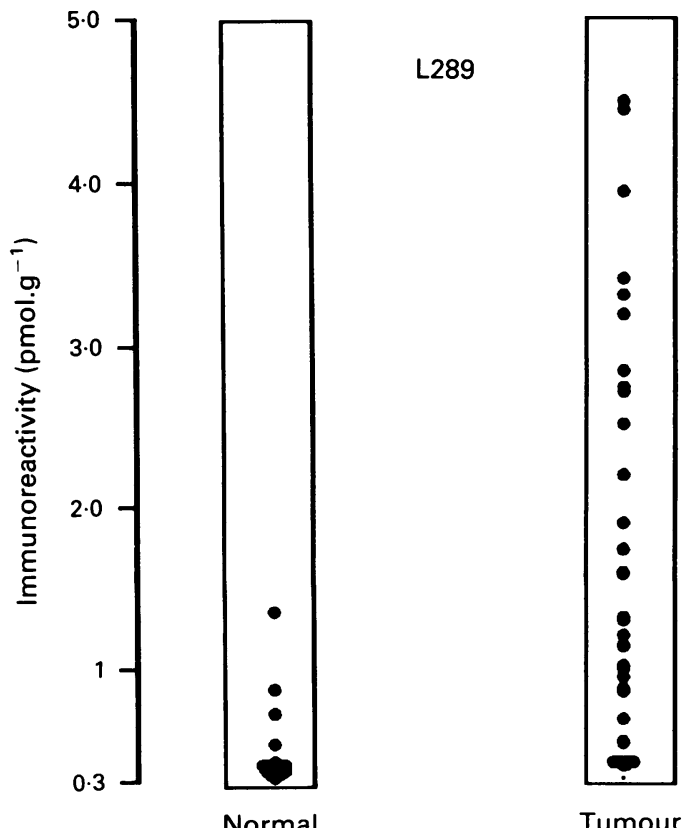

Tumour

Figure 3: As Figure 2, showing data obtained using antibody L289. Note that only nine of 44 samples of normal colon mucosa contained detectable immunoreactivity compared with 40 of 44 tumour extracts. 
Figure 4: As Figure 2, showing data obtained using antibody 109-21.

Detectable concentrations of immunoreactive material

were found in seven of 44

extracts of normal tissue and 20 of 44 tumour extracts.

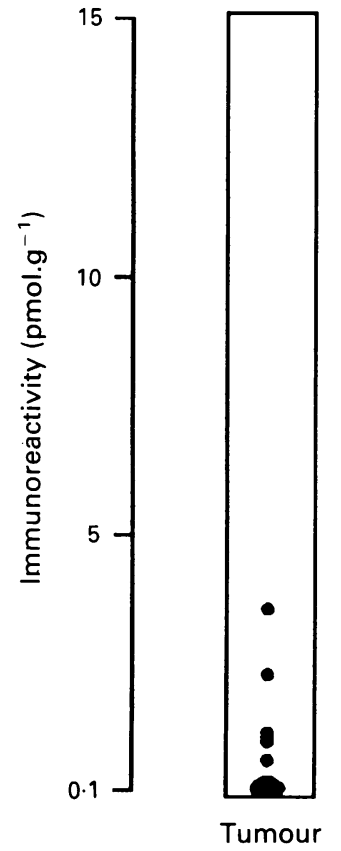

There were no differences in the concentrations of progastrin derived peptides measured by the various antibodies in tumours taken from rectum compared with sigmoid colon (which were the two largest subgroups). In addition, there was no correlation between concentrations measured in any of the four assays and the Dukes' stage of the tumour.

GEL FILTRATION

The samples with the highest concentrations of immunoreactivity in assays with LW60 and L289 were fractionation on Sephadex G50 (Fig 6). The pattern of immunoreactivity with LW60 was variable. A peak corresponding to the C-terminal tryptic fragment of progastrin was consistently identified. In addition, however, there were also peaks of variable proportion that eluted earlier. We have previously seen these peaks in material derived from human antrum

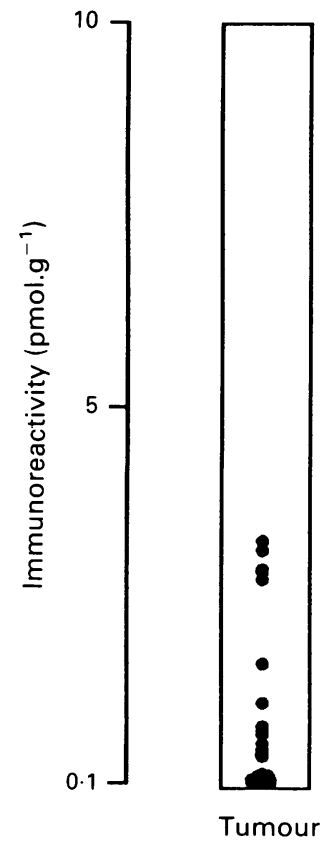

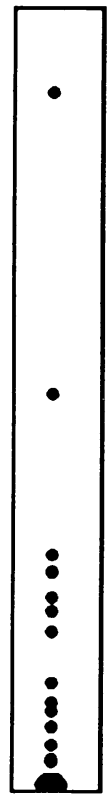

Normal

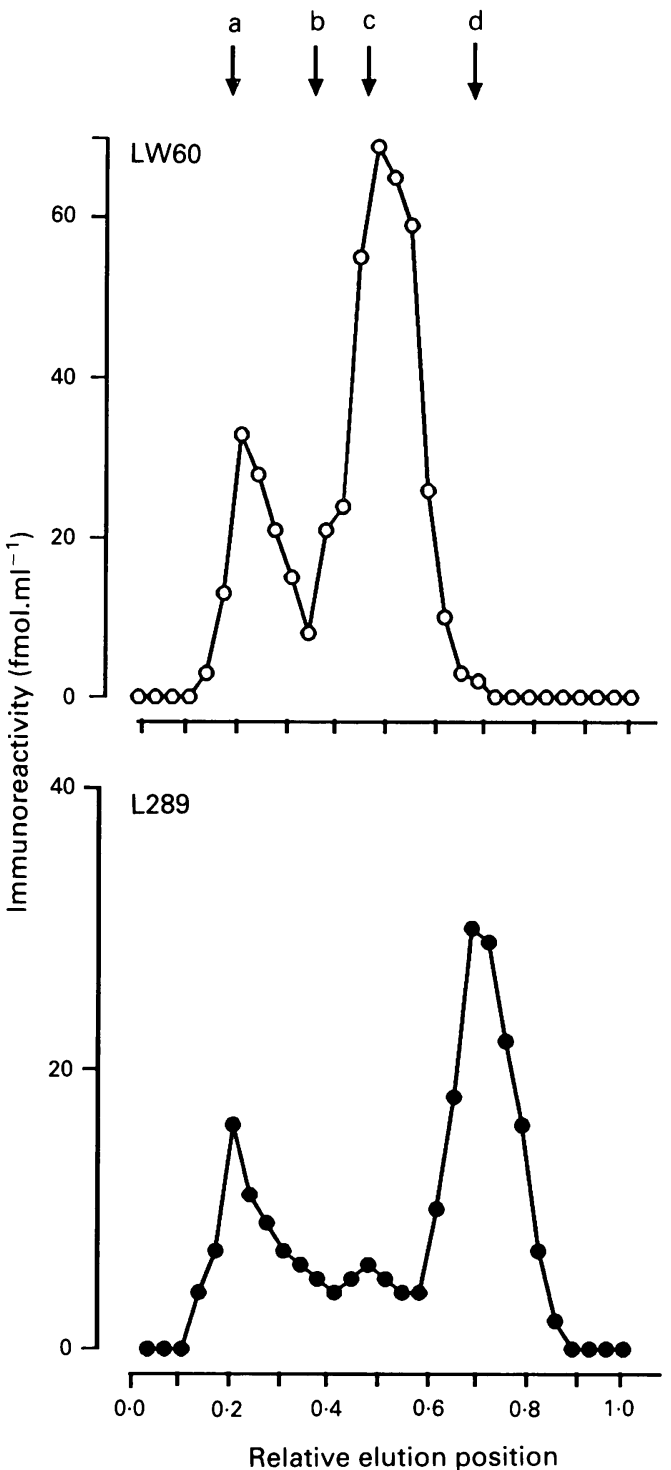

Figure 6: Separation on Sephadex G50 of a tumour extract assayed with antibody L289 and LW60. Arrows at top indicate elution positions of (a) progastrin, $(b)$ G17-extended at $C$-terminus, (c) progastrin $C$-terminus tryptic fragment. $(d)$ A late eluting peak reacts with $L 289$ but not $L W 60$ (its nature is as yet uncertain). Note major peaks corresponding to progastrin and its flanking peptide.

where they are generally less than $5 \%$ of the total. The amounts of material so far available have been insufficient for full chemical characterisation but we have tentatively identified them as corresponding to G34 and G17 extended through the $\mathrm{C}$-terminus to include the $\mathrm{C}$-terminal fragment of progastrin. A minor peak corresponding to intact progastrin was also identified in assays using LW60. In addition L289 reacted with material that emerged in the characteristic position of progastrin. Unexpectedly, however, L289 also reacted with a further peak of material that has not so far been identified in antral extracts and that emerged relatively late and did not correspond to one of the LW60 peaks. Assays with L2 and 109-21 showed small peaks that had the chromatographic properties of G17 and its Gly-extended variant, respectively (not shown).

\section{Discussion}

Normal
The main finding of this study is that virtually all
Figure 5: As Figure 2, showing data obtained using antibody L2. Detectable activity was found in 25 of and 19 of 44 extracts of tumour. 
the colorectal cancers studied contained low, but detectable, concentrations of progastrin derived peptides. The same spectrum of peptides was also found in extracts of normal colon mucosa but in still lower concentrations. For the most part, the biologically active forms of gastrin that is, C-terminally amidated peptides, were found in much lower concentrations than other progastrin derived peptides. Taking these observations together with other data, ${ }^{212}$ we conclude that the gastrin gene is likely to be expressed in many colorectal cancers, although the capacity to process progastrin to a biologically active product seems to be poorly developed.

The present study has made use of antibodies that react with progastrin itself, its major active products, Gly-extended biosynthetic intermediates, and its C-terminal tryptic fragment. There are three major steps in the production of amidated gastrins from progastrin: ${ }^{19}$ endopeptidase cleavage, carboxypeptidase trimming of Arg residues and conversion of Gly-extended to amidated products. In normal G-cells of the antrum there are approximately similar concentrations of amidated gastrins and the C-terminal progastrin fragment; concentrations of progastrin and of Gly-extended gastrins are about $10 \%$ those of the cleaved C-terminal fragment. ${ }^{19}$ Assays using antibodies L289 and LW60 provide the capacity to detect intact progastrin (without any processing) or the fragment produced after the first endopeptidase cleavage. This distinction is crucial in the present context, because it appears that material resulting from endopeptidase cleavage is rather commonly encountered whereas material generated at the later stages (Gly-extended and amidated products) is less common. In assays using L289 and LW60, immunoreactive material was more commonly found in tumours than control tissue. We conclude therefore that progastrin is frequently produced by colorectal cancers but the phenotype for processing to amidated products is usually not well developed. Although progastrin derived peptides were more abundant in tumour than control extracts, there were nevertheless detectable amounts of activity in all normal samples using assays with LW60, and in a high proportion of assays of normal samples using antibody L2. It seems possible that this material originates from rare mucosal endocrine cells expressing the gastrin gene. We are presently undertaking further studies using the same panel of antibodies in an attempt to localise each of the precursor peptides in sections from both normal mucosa and tumours.

Patients with colorectal cancer are reported to have postprandial hypergastrinaemia which returns to normal after tumour resection. Wong et $a l,{ }^{20}$ consider that the raised gastrin originates in the antrum rather than the tumour. In the present study, basal plasma gastrin concentrations in the group as a whole were within the normal range, although there was a subset in which basal gastrin was raised. This accords with work of others, ${ }^{2021}$ although the hypergastrinaemic subgroup in our study was a smaller proportion of the total than previously reported (11\%, compared with $36-40 \%)$. Nevertheless, it seems that colorectal tumours are unlikely to make a consistently important contribution to circulating plasma gastrin, although raised postprandial gastrin of antral origin may be significant as a mitogenic factor in promoting tumour growth.

In peptide producing endocrine cells the main secretory products pass from the Golgi to the cell exterior through the so called regulated route that is, in secretory granules that are released by exocytosis on stimulation. The post translational processing mechanisms that convert progastrin to amidated peptides are known to operate at the post Golgi level on this pathway. ${ }^{1922}$ An alternative secretory pathway, the constitutive route, takes material direct from the Golgi to the cell surface, is present in all cells, and is unregulated in the sense that exocytosis is not controlled by external factors. The cellular machinery of the regulated pathway and associated processing enzymes may be poorly represented in colorectal cancer cells, and consequently the apparent failure to process progastrin derived peptides in these tumours is not surprising. The signal sequence in preprogastrin - that is, residues $1-21,{ }^{14}$ is sufficient to ensure sequestration into the cisternal space of the endoplasmic reticulum so that the peptides we have measured are likely to be localised to the secretory pathway, most probably taking the constitutive route to the exterior. The generally rather low concentrations of material measured in our extracts (compared with antral extracts) are consistent with material passing direct to the cell surface without residence in storage granules.

The potential autocrine growth effects of gastrin in colorectal cancer have previously been studied using cell lines. ${ }^{8-12}$ Our data suggest that the biologically active amidated peptides that are potential mediators of these actions cannot be more than a small proportion of the total progastrin produced. It would appear, however, that some tumours contain more active product than others; thus autocrine growth promoting effects that might be attributable to gastrin are in any case only likely to be a property of a subset of tumours.

We are grateful to Mrs C Carter and Miss F Littler for help in preparing the manuscript and to the Medical Research Council for financial support.

1 Townsend CM, Beauchamp RD, Singh P, Thompson JC. Growth factors and intestinal neoplasms. Am $\mathcal{F}$ Surg 1988; Growth factors

2 Baldwin GS, Casey A, Mantamadiotis T, McBride K, Sizeland $A M$, Thumwood CM. PCR cloning and sequence of gastrin mRNA from carcinoma cell lines. Biochem Biophys Res Commun 1990; 170: 691-7.

3 Watson SA, Durrant LG, Morris DL. Gastrin dependence of human colorectal and gastric tumours. Gut 1988; 29: A738.

4 Singh P, Rae-Venter B, Townsend CM, Khalil T, Thompson JC. Gastrin receptors in normal and malignant gastrointestinal mucosal: age-associated changes. Am $\mathcal{f}$ Physiol 1985; 249: G761-9.

5 Winsett OE, Townsend CM, Glass EJ, Thompson JC. Gastrin stimulates growth of colon cancer. Surgery 1986; 99: 302-7.

Guo Y-S, Baijal M, Jin G-F, Thompson JC, Townsend CM, Singh P. Growth promoting effects of gastrin on mouse colon cancer cells in vitro: absence of autocrine effects. colon cancer cells in vitro: absence

7 Kusyk G, McNeil NO, Johnson LR. Stimulation of growth of a colon cancer cell line by gastrin. Am 7 Physiol 1986; 251 : G597-601.

8 Beauchamp RD, Townsend CM, Singh P, Glass EJ, Thompson JC. Proglumide a gastrin receptor antagonist, inhibits growth of colon cancer and enhances survival in mice. Ann Surg 1985; 202: 303-9.

9 Hoosein NM, Kiener PA, Curry RC, Rovati LC, McGilbra DK, Brattain MG. Antiproliferative effects of gastrin receptor antagonists and antibodies to gastrin on human colon carcinoma cell lines. Cancer Res 1988; 48: 7179-83. 
10 Hoosein NM, Kiener PA, Curry RC, Brattain MG. Evidence for autocrine growth stimulation of cultured colon tumor cells by a gastrin/cholecystokinin-like peptide. Cell Res 1990; 186: 15-21.

11 Smith JP, Solomon TE. Effects of gastrin, proglumide, and somatostatin on growth of human colon cancer. Gastroenterology 1988; 95: 1541-8.

12 Watson SA, Durrant LG, Wencyk PM, Watson AL, Morris DL. Intracellular gastrin in human gastrointestinal tumor cells. I Natl Cancer Inst 1991; 83: 866-71.

13 Pauwels S, Desmond H, Dimaline R, Dockray GJ. Identification of progastrin in gastrinomas, antrum and duodenum by a novel radioimmunoassay. $\mathcal{F}$ Clin Invest 1986; 77: 37681.

14 Desmond H, Pauwels S, Varro A, Gregory H, Young J, Dockray GJ. Isolation and characterization of the intact gastrin precursor from a gastrinoma. FEBS Lett 1987; 210: 185-8.

15 Varro A, Desmond H, Pauwels S, Gregory H, Young J, Dockray GJ. The human gastrin precursor: characterization of phosphorylated forms and fragments. Biochem $\mathcal{F} 1988$; 256: $951-7$.

16 Dockray GJ, Best L, Taylor IL. Immunochemical characteri- zation of gastrin in pancreatic islets of normal and genetically obese mice. F Endocrinol 1977; 72: 143-51.

17 Azuma T, Taggart RT, Walsh JH. Effects of bombesin on the release of glycine-extended progastrin (gastrin G) in rat antral tissue culture. Gastroenterology 1987; 93: 322-9.

18 Nemeth J, Varro A, Bridson J, Walker R, Dockray GJ. Increased tissue concentrations of the gastrin precursor in patients treated with omeprazole. Eur $\mathcal{f}$ Clin Invest (in patients treated with omeprazole. Eur f Clin Invest (in

9 Dockray GJ. Selective processing of peptides in gastric endocrine cells. In: Håkanson $\mathrm{R}$, Sundler $\mathrm{F}$, eds. The stomach as an endocrine organ. Amsterdam: Elsevier, 1991: 197-210.

20 Wong K, Beardshall K, Waters CM, Calam J, Poston GJ. Postrprandial hypergastrinaemia in patients with colorectal cancer. Gut 1991; 32: 1352-4.

21 Palmer-Smith J, Wood JG, Solomon T. Elevated gastrin levels in patients with colon cancer or adenomatous polyps. Dig Dis Sci 1989; 34: 171-4.

22 Rahier J, Pauwels S, Dockray GJ. Biosynthesis of gastrin: Localization of the precursor and peptide products using Localization of the precursor and peptide products using
electron microscopic-immunogold methods. Gastroelectron microscopic-imm
enterology 1987; 92: 1146-52. 